\title{
Paulina Wierzba
}

Uniwersytet im. Adama Mickiewicza w Poznaniu

\section{Tożsamość homoseksualnych kobiet - dramat czy konstruktywna alternatywa?}

Celem niniejszego aRTYKuŁu jest ukazanie najważniejszych problekobiet, jakie można obserwować we współczesnym społeczeństwie. Homoseksualizm kobiecy nie jest zjawiskiem nowym, jednak właśnie zachodzące w ostatnich latach przemiany społeczno-kulturowe odgrywają znaczącą rolę w rozpowszechnianiu się homoseksualnego stylu życia oraz wywierają znaczący wpływ na kształt tożsamości mniejszości seksualnych. Rodzi to wątpliwości dotyczące tego, czy homoseksualizm może stanowić konstruktywną alternatywę dla tradycyjnego, heteroseksualnego stylu życia, czy jest dla lesbijek przede wszystkim źródłem dylematów i kryzysu tożsamości. Swoje rozważania ilustruję fragmentami internetowych forów dyskusyjnych, prowadzonych przez homoseksualne kobiety. Internet stanowi bowiem obecnie ważną platformę wymiany poglądów na temat homoseksualnego stylu życia, jest bezpieczną przestrzenią, w której lesbijki mogą się ujawnić, dzielić swoimi niepokojami i wspierać nawzajem.

Problemy związane z kształtowaniem się tożsamości homoseksualnej u kobiet wiążą się przede wszystkim ze zjawiskiem przekazywania w zachodnich społeczeństwach jednostkom różnych, często sprzecznych ze sobą wizji tej samej rzeczywistości. Pomimo postępujących przemian społeczno-kulturowych związanych z ponowoczesnością, jednostki wciąż ulegają w dużym stopniu tradycyjnym, modernistycznym wpływom. Do dziś bardzo dużą rolę w kształtowaniu tożsamości odgrywają tradycyjne instytucje, wyznaczające kobietom przede wszystkim konkretne role do odegrania. W społeczeństwie wciąż echem odbija się stereotypowa wizja roli kobiety. Przypisuje się ją do sfery prywatnej i obciąża odpowiedzialnością za wypełnianie obowiązków domowych oraz przede wszystkim narzuca na nią obowiązek wyjścia za mąż, rodzenia i wychowywania dzieci ${ }^{1}$. Ciekawie opi-

${ }^{1}$ A. Titkow, D. Duch-Krzystoszek, B. Budrowska, Nieodptatna praca kobiet mity, realia, perspektywy, Warszawa 2004, s. 24-25. 
suje to zjawisko wypowiedź jednej z internautek: „Wolność? Gdzie jest ta wolność, o której się wszędzie tak trąbi? Jakoś jej nie dostrzegam. Kobiety w dalszym ciągu traktuje się jak domowe popychadła, nie ma opcji, żeby bez robienia szumu i bez bycia wyklętą z rodziny kobieta chociażby zrezygnowała z macierzyństwa i zdecydowała się na karierę zawodową. Nie mówiąc już o decyzji o byciu z drugą kobietą. O zgrozo"2.

Tradycyjny sposób pojmowania ról płciowych opiera się na podziale na BIOLOGIE - NATURE - KOBIETE i KULTURE - WYMIAR SPOŁECZNY - MĘŻCZYZNĘ. Mężczyzna wolny jest według niego od determinizmu biologicznego, stanowiącego uniwersalną normę dla gatunku ludzkiego. Kobiety zaś definiuje się poprzez ich płeć biologiczną. Stereotypowe spojrzenie na relację płci ma olbrzymie znaczenie w kształtowaniu tożsamości homoseksualnych kobiet, pokazuje bowiem siłę tradycji wpływającej na życie społeczne, do której lesbijki starają się dopasować ${ }^{3}$. Interesująco ilustruje to zjawisko fragment jednego z analizowanych przeze mnie blogów: „My, kobiety, jesteśmy przede wszystkim cielesne i biologiczne, mamy rodzić dzieci - jedno po drugim. Kobieta to przede wszystkim chodzący inkubator. Mężczyźni mają lepiej, wszystko im wolno. Nikt gejowi nie mówi, że rezygnując z posiadania potomstwa, marnuje swój materiał genetyczny, lesbijki nieustannie odczuwają to, że postrzega się je jak obciążenie dla społeczeństwa, nie masz dziecka - jesteś bezużyteczna - nie jesteś prawdziwą kobietą"4.

Peter Berger i Thomas Luckmann5, analizując wpływ społeczeństwa na kształtowanie się ludzkiej tożsamości stwierdzili, że stabilna i dokładnie określona tożsamość jednostek może uformować się jedynie w społeczeństwach o bardzo prostej strukturze. Tylko w takich warunkach może ona odwzorować w stu procentach obiektywną rzeczywistość, w której się znajduje ${ }^{6}$. W poprzedzającym naszą epokę modernizmie, kobiety i mężczyzn obowiązywała jasno określona, heteroseksualna norma dotycząca tożsamości seksualnej. Członkowie społeczeństwa dążyli do tego, by być tacy sami i postępować zgodnie

${ }^{2}$ Adres internetowy: http://lesbijka.phorum.pl/viewtopic.php?t=259, 5.01.2011 r.

${ }^{3}$ A. Titkow, D. Duch-Krzystoszek, B. Budrowska, Nieodptatna..., op. cit., s. 26.

${ }^{4}$ Adres internetowy: http://lesbijka.phorum.pl/viewtopic.php?t=267, 6.01.2011 r.

${ }^{5}$ Zob. A. Kotlarska-Michalska, Czynniki utrudniające proces tworzenia się tożsamości wspótczesnej młodzieży, [w:] Tożsamość a wspótczesność. Nowe tendencje i zagrożenia , red. B. Harwas-Napierała, H. Liberska, Poznań 2007, s. 137-139.

${ }^{6}$ Zob. A. Kotlarska-Michalska, Czynniki..., op. cit, s. 137-139. 
z ogólnie przyjętym schematem postępowania - byli jakby trybikami w maszynie, którą było społeczeństwo: w określonym czasie odgrywali ściśle określona role. W epoce modernizmu kobietom trudno było wyobrazić sobie życie poza instytucją małżeństwa i rodziny. Biografia każdego z członków społeczeństwa była bowiem ściśle określona. Rodzina przechodziła przez kolejne następujące po sobie fazy, w których każdy z jej członków wypełniał przypisaną mu rolę. Etapy życia kobiety były przewidywalne, powiązane z przeszłością, teraźniejszością oraz przyszłością. Rola ówcześnie żyjącej kobiety była nierozerwalnie związana ze sferą domową. Z przykładnej córki kobieta przeobrażała się w żonę, później w matkę, by w jesieni swojego życia stać się babcią i opiekować dziećmi swojego potomstwa. Myśl dotycząca prowadzenia odmiennego stylu życia, posiadania odmiennej tożsamości (w tym seksualnej) nie przychodziła kobietom do głowy, ponieważ nieodwołalnie przynależały one do tradycyjnej instytucji rodziny i nie miały względem tego żadnej alternatywy7. Rodzina epoki modernizmu, będąc solidną podstawą reprodukcji i strażnikiem ładu społecznego, nie gwarantowała jednak tego, co w czasach współczesnych uważa się za najważniejsze - poczucia jednostkowego szczęścia ${ }^{8}$.

Ponowoczesność zmienia reguły gry9 . W ostatnich latach możemy obserwować liberalizację współczesnej rzeczywistości związaną z procesem indywidualizacji. Pojawiły się nowe wartości i normy, np. autonomia, szacunek do samego siebie, samookreślanie. Kobiety uwolniły się w dużej mierze od tradycyjnych zobowiązań oraz więzi społecznych. Płeć czy pochodzenie społeczne przestały determinować osobiste biografie jednostek ${ }^{10}$. Współczesna kobieta ma więc prawo do decydowania o samej sobie, lecz jednocześnie jest również za siebie w pełni odpowiedzialna ${ }^{11}$. Daje to homoseksualnym kobietom wolność, o jakiej wcześniej nie mogło być mowy.

W dobie współczesnych społeczeństw zaczyna obowiązywać zasada pluralizmu. Poszukiwanie i odkrywanie różnorodności staje się cechą współczesnego świata. Kształtują się społeczeństwa posttradycyj-

${ }^{7}$ Z. Melosik, T. Szkudlarek, Kultura, tożsamość, edukacja, migotanie znaczeń, Kraków 1998, s. 50.

${ }^{8}$ Zob. K. Slany, Dywersyfikacja form życia rodzinnego we wspótczesnym świecie. Przykład związków homoseksualnych, [w:] Homoseksualizm, perspektywa interdyscyplinarna, red. K. Slany, B. Kowalska, M. Śmietana, Kraków 2005, s. 76-78.

${ }^{9}$ Z. Melosik, T. Szkudlarek, Kultura..., op. cit., s. 78.

${ }^{10}$ A. Kwak, Rodzina w dobie przemian: małżeństwo i kohabitacja, Warszawa 2005, S. $113-115$.

${ }^{11}$ Z. Krasnodębski, Upadek idei postępu, Warszawa 1991, s. 74-77. 
ne, postrodzinne, instytucjonalizują się nowe formy życia intymnego i seksualnego. Poddano w wątpliwość absolutny wymiar heteroseksualnej normy dotyczącej ludzkiej seksualności ${ }^{12}$. Tożsamość seksualna stała się wielką narracją XXI wieku, pełniąc taką funkcję w refleksji nad wolnością i prawami człowieka, jaką płeć i rasa miały w przeszłości $^{13}$.

Coraz więcej kobiet decyduje się na okresowe bądź stałe przyjęcie tożsamości homoseksualnej oraz życie w jednopłciowych związkach. Wiąże się to zarówno z zagrożeniami, jak i szansami pozytywnych społecznych przemian. W związkach homoseksualnych mamy do czynienia z zupełnie nową konstrukcją normalności - opierającą się przede wszystkim na symetrycznych relacjach między partnerami - niekoniecznie wiąże się ona natomiast z legalizacją, trwałością czy przywiązaniem ${ }^{14}$.

Anthony Giddens uważa, iż w pewnym stopniu układ homoseksualny przewyższa tradycyjną instytucję rodziny - tworząc atmosferę całkowitej równości i bezpieczeństwa ${ }^{15}$. Można wymienić pozytywne wzory, według których powstają partnerskie układy między kobietami (wyróżnili je Michael Weeks i Jason Donovan ${ }^{16}$ ). W związkach homoseksualnych jest dużo więcej miejsca na równość między partnerami, bo takie związki nie opierają się na tradycyjnych, kulturowych i społecznych założeniach, stanowiących podstawę związków heteroseksualnych. Lesbijki kształtują swoje związki tak, by uniknąć nierówności i nierównowagi sił, co jest typowe dla związków między osobami przeciwnej płci. Poza tym budując związek, homoseksualne kobiety dowolnie ustalają między sobą zasady i sposób jego funkcjonowania - podczas, gdy w relacji między heteroseksualistami kobietom przypada na ogół praca w domu oraz wychowywanie dzieci, w związkach homoseksualnych nie ma podobnych oczekiwań. Wyróżnia je często wzajemnie zaufanie, gotowość do czynnego pokonywania trudności i wspólna „praca emocjonalna” nad budowaniem głębokiej relacji ${ }^{17}$.

Kształtowanie tożsamości seksualnej jest w kontekście ścierania się ze sobą modernistycznej i ponowoczesnej rzeczywistości bardzo

${ }^{12}$ K. Slany, Dywersyfikacja..., op. cit., s. 22-40.

${ }^{13}$ P. Leszkowicz, T. Kitliński, Miłość i demokracja. Rozważania o kwestii homoseksualnej w Polsce, Kraków 2005, s. 19.

${ }^{14}$ K. Slany, Dywersyfikacja..., op. cit., s. 22.

${ }^{15}$ A. Giddens, Socjologia, Warszawa 2009, s. 154.

${ }^{16}$ Ibidem, s. 22-26.

${ }^{17}$ Ibidem, s. 156. 
trudnym zadaniem - łączy się bowiem często z wyborem pomiędzy własnym szczęściem i wolnością, a posiadaniem minimum bezpieczeństwa, jakiego potrzebuje każdy człowiek ${ }^{18}$. Tradycyjny, modernistyczny sposób myślenia pokutuje do dzisiaj - wiele homoseksualnych kobiet decyduje się na rezygnację z własnych potrzeb i marzeń. Istnieje o wiele więcej osób, które miały doświadczenia homoseksualne lub mają wyraźne skłonności homoseksualne niż wskazuje na to liczba ludzi prowadzących jawne gejowskie życie ${ }^{19}$. Wiele lesbijek i gejów decyduje się na ukrywanie swojej orientacji i prowadzenie heteroseksualnego stylu życia. Nieujawnianie homoseksualnej tożsamości otoczeniu jest często wybieraną przez lesbijki alternatywą dla homoseksualnego stylu życia. Stają się one żonami i matkami, by pozbyć się poczucia społecznej nieadekwatności i dostosować się do oczekiwań społeczeństwa. Taki styl życia jest źródłem wielu dramatów. Ukazuje to następująca wypowiedź: „Niby mamy współcześnie wolność, ale ja jej w sobie nie mam - mimo, że jestem lesbijką i jestem tego pewna, nie wyobrażam sobie życia bez męża i rodziny. Kobieta bez męża jest nikim. Bez mężczyzny nie czułabym się bezpiecznie. I tak - wprawdzie kobiety mi w głowie, ale mąż u boku i dziecko w drodze. Nie mogłabym inaczej"20.

Kształt seksualnej tożsamości oraz styl życia homoseksualnych kobiet zależy w dużej mierze od środowiska z jakiego pochodzi konkretna jednostka, posiadanego przez nią habitusu i kapitału kulturowego. Pierre Bourdieu wprowadził pojęcie habitusu, oznaczające system trwałych, dających się przetransportować dyspozycji. Habitus jest zbiorową nieświadomością, która łączy osoby o podobnym doświadczeniu i pozycji społecznej, co kształtuje u jednostek podobne postrzeganie świata i wyznacza możliwości podejmowania osobistych wyborów. Habitus łączy się z posiadaniem ograniczonego kapitału kulturowego, który jest jedną z podstawowych, ukrytych barier na drodze rozwoju jednostek. Kapitał kulturowy często uniemożliwia homoseksualnym kobietom funkcjonowanie zgodne z ich potrzebami, narzucając sposób życia, obowiązującą fasadę, poprzez którą muszą one funkcjonować, zmusza ich do ukrywania orientacji seksualnej przed otoczeniem. W ramach określonych środowisk pochodzenia jednostki funkcjonują homogeniczne habitusy, co przesądza o podobieństwie zasobów jednostek wchodzących w ich skład i decyduje o podejmowa-

\footnotetext{
${ }^{18}$ Z. Bauman, Ponowoczesność jako źródło cierpień, Warszawa 2000, s. 10.

${ }^{19}$ Ibidem, s. 55 .

${ }^{20}$ Adres internetowy: http://lesbijka.phorum.pl/viewtopic.php?t=278, 1.01.2011 r.
} 
nych przez nich wyborach dotyczących stylu życia ${ }^{21}$. Ukrywanie homoseksualizmu pozwala na uniknięcie negatywnej reakcji otoczenia, która wciąż jest powszechna, zwłaszcza w tradycyjnych, zamkniętych społecznościach, charakteryzujących się ograniczonym kapitałem kulturowym. Kobiety ukrywające swoją orientację seksualną przed otoczeniem pochodzą najczęściej z podobnych środowisk: wychowywały się w mniejszych miastach, w tradycyjnych, katolickich rodzinach. Zachowania, sposób myślenia i kształt tożsamości jednostki są w wielu przypadkach uzależnione od tego, jaka była jej dotychczasowa historia i losy. Będąc członkami określonej zbiorowości, jesteśmy zobowiązani do postępowania zgodnego z zasadami w niej panującymi, a te wykluczają bardzo często jawne zachowania homoseksualne.

Ukrywanie homoseksualizmu jest wielkim zagrożeniem dla osobowości jednostek i powoduje kierowanie poszukiwań tożsamości poza siebie samych, co może prowadzić do utracenia sensu własnego „Ja”. Wiele osób, w tym duże grono homoseksualistów, chcąc być akceptowanymi przez wszystkich uczestników życia społecznego, ostatecznie „dostrajają się” do tego, czego oczekuje od nich otoczenie, rezygnując zupełnie z własnych pragnień oraz uczuć, ukrywając je przed otoczeniem. Wielu członków współczesnego społeczeństwa, a wśród nich wyrzekający się własnej tożsamości homoseksualiści, stało się „dziurawymi ludźmi”, którzy mają nikłe zrozumienie tego, kim są oraz co czują. Charakteryzuje ich wewnętrzna pustka: „dziurawi ludzie” przypominają zestaw luster, odbijających bezmyślnie to, czego inni od nich oczekują ${ }^{22}$.

Społeczeństwo ma realny wpływ jedynie na formy ekspresji zachowań homoseksualnych, może je regulować poprzez normy społeczne i hamować, lecz nie jest w stanie ich wyeliminować ${ }^{23}$. Realizacja homoseksualnych potrzeb związana z koniecznością wyboru homoerotycznego sposobu życia oznacza najczęściej transgresję, czyli konieczność zmiany środowiska społecznego - przejścia z jednej grupy do innej, bądź funkcjonowania na granicy tych dwóch grup, a więc postępowania niezgodnego z obowiązującymi w nich zasadami, co często wywo-

${ }^{21}$ Zob. P. Bourdieu, Struktury, habitus, praktyki, [w:] Wspótczesne teorie socjologiczne, t. 2., red. A. Jasińska-Kania, L. Nijakowski, J. Szacki, M. Ziółkowski, Warszawa 2006, s. 543-545.

${ }^{22}$ G. Corey, M. Schneider-Corey, Sens życia i wartości, [w:] Mosty zamiast murów, red. J. Steward, Warszawa 2002, s. 163.

${ }^{23}$ Zob. A. Długołęcka, Ksztaltowanie się tożsamości homoseksualnej, [w:] Homoseksualizm - perspektywa interdyscyplinarna, red. K. Slany, B. Kowalska, M. Śmietana, Kraków 2005, s. 66. 
łuje u homoseksualistów dezorientację i poczucie nieadekwatności ${ }^{24}$. Prowadzenie podwójnego życia jest olbrzymim ciężarem dla lesbijek oraz źródłem zagubienia osób homoseksualnych, nie potrafią oni bowiem zdecydować, kim pragną być i w jaki sposób chcą żyć. Paradoksem współczesnego świata jest fakt, że chociaż cieszymy się nieskrępowaną wolnością, mamy swobodę w podejmowaniu decyzji odnośnie stylu życia czy seksualnych preferencji i nasze życie wydaje się być dużo łatwiejsze niż poprzednich pokoleń, wciąż nie jesteśmy w pełni usatysfakcjonowani. Nieustannie doświadczamy niepokojów dotykających nas samych, dotyczących naszego miejsca w świecie ${ }^{25}$.

Przedstawione w pracy rozważania dotyczące pozytywnych i negatywnych aspektów przemian tożsamości seksualnej, będących konsekwencją rozpowszechniania się homoseksualnego stylu życia, nie pozwalają na sformułowanie odpowiedzi na zawarte w temacie artykułu pytanie, czy są one dla jednostek dramatem czy konstruktywną alternatywą. Jednoznaczna odpowiedź na to pytanie nie istnieje. Nie ulega jednak wątpliwości, że przemiany tożsamości seksualnej są ogromnym wyzwaniem dla współczesnego, ponowoczesnego społeczeństwa i zjawiskiem wartym uwagi i interpretacji. Mam nadzieję, że udało mi się poruszyć i wyjaśnić podstawowe kwestie związane z przemianami tożsamości homoseksualnych kobiet, uwzględniając przede wszystkim kontekst przemian kultury zachodniej i relacji osób homoseksualnych ze społeczeństwem.

\section{SUMMARY}

THE ARTICLE Identity of Homosexual Women - Drama or a Constructive Alternative? presents the most important aspects of homosexual identity changes, which can be observed in modern society, especially as far as problems of homosexual women are concerned. The main goal of this article is to show the crash of modernism and postmodernism ideologies connected to cultural pluralism and axiological relativism and their consequences for the shape of lesbian's identity. Reflections are illustrated by the statements from the homosexual women's websites. As a result, main issues can be understood better.

${ }^{24}$ P. Fijałkowski, Homoseksualizm wykluczenie transgresja akceptacja, Warszawa 2009, s. 159.

${ }^{25}$ G. Corey, M. Schneider-Corey, Sens..., op. cit., s. 163. 


\section{NOTA O AUTORCE}

Paulina Wierzba [wierzba@amu.edu.pl] - magister socjologii i pedagogiki na Uniwersytecie im. Adama Mickiewicza w Poznaniu, doktorantka w Zakładzie Socjologii Edukacji na Wydziale Studiów Edukacyjnych Uniwersytetu im. Adama Mickiewicza w Poznaniu. Jej zainteresowania naukowe ogniskują wokół przemian współczesnej kultury, przede wszystkim w kontekście społecznego konstruowania i przeobrażeń tożsamości. 